\title{
In vitro Interaction of Nandrolone with Calcium Nitrate, Magnesium Sulfate and Potassium Permanganate in Aqueous Medium
}

\author{
Mehedi Afzal $^{1}$, Md. Zakir Sultan², Rehana Begum, Asma Rahman², \\ Md. Shah Amran ${ }^{1}$ and Md. Amjad Hossain ${ }^{1}$ \\ ${ }^{1}$ Department of Pharmaceutical Chemistry, Faculty of Pharmacy, University of Dhaka, \\ Dhaka-1000, Bangladesh \\ ${ }^{2}$ Drug Analysis and Research Laboratory, Centre for Advanced Research in Sciences, \\ University of Dhaka, Dhaka-1000, Bangladesh
}

\begin{abstract}
Nandrolone is an anabolic steroid drug that increases production and urinary excretion of erythropoietin. The drug is indicated with calcium nitrate, magnesium sulfate and potassium permanganate as concomitant uses. Therefore, there is a chance of interactions during concomitant use. Hence, we evaluated the interactions monitored by UV, conductometric titration and Ardon's spectrophotometric methods of nandrolone with calcium nitrate, magnesium sulfate and potassium permanganate at the ratio of $1: 1$ at different pHs. It was found that nandrolone did not form any stable complexes at the ratio of 1:1 with the above mentioned salts.
\end{abstract}

Key words: Nandrolone, drug-drug interaction, drug-metal interaction.

\section{INTRODUCTION}

Now-a-days, various mineral supplements along with drug therapy are a common and useful practice for the treatment of diseases where minerals and drugs are given concurrently. The drugs may exhibit effects independently or may interfere or interact with each other. The interaction may be agonist or antagonist of one drug by another. Sometimes, the combination therapies are beneficial to the patients and sometimes it causes serious negative effects. Patients with diseases like kidney/heart transplantation or failure, diabetes mellitus and hypertension, anemia, bone and lipid disorders and so on are frequently prescribed numerous medications. Concomitant use of a large number of medications may have increased risks for drug interactions. Drug interactions are classified into two classespharmacodynamic and pharmaco-kinetic interactions. Pharmacodynamic interactions include those that result in additive or antagonistic pharmacological effects. Pharmacokinetic interac-tions involve induction or inhibition of metabolizing enzymes in

Correspondence to: Md. Amjad Hossain

E-mail: amranms@du.ac.bd

Dhaka Univ. J. Pharm. Sci. 11(2): 93-99, 2012 (December) the liver or elsewhere, displacement of drug from plasma protein binding sites, alterations in gastrointestinal absorption, or competition for active renal secretion. ${ }^{1,2}$ Therefore, drug interactions definitely alter the pharmacological effects. The effects of a moderate interaction may cause deterioration in the patient's clinical status, resulting in additional treatment, hospitalization, and/or an extended hospital stay. The effects of a major interaction are potentially life-threatening or can lead to permanent damage. ${ }^{3,4}$ Therefore, in our research we studied the in vitro interaction of nandrolone with calcium nitrate, magnesium sulfate and potassium permanganate in aqueous medium.

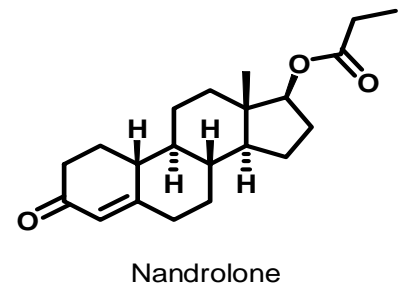

Nandrolone is an anabolic steroid drug which increases production and urinary excretion of erythropoietin. It may also have a direct action on bone marrow. Nandrolone binds to the androgen 
receptor to a greater degree than testosterone. Nandrolone is used in the treatment of refractory deficient red cell production anemias, breast carcinoma, hereditary angioedema, antithrombin-III deficiency, fibronogen excess, growth failure and Turner's syndrome. It is also indicated in the prophylaxis of hereditary angioedema. It was also used to treat osteoporosis in post menopausal women. ${ }^{5,6}$ Calcium nitrate is a source of calcium which is needed for building our bones. ${ }^{7}$ Magnesium and manganese both exert synergistic effect in the pharmacological activity of calcium by increasing the deposition rate of the calcium in bones.,

The drug is indicated with calcium nitrate, magnesium sulfate and potassium permanganate to the patient sufferings from refractory deficient red cell production anemias, breast carcinoma, hereditary angioedema, antithrombin-III deficiency, fibronogen excess, growth failure and Turner's syndrome with osteoporosis. ${ }^{7}$ Therefore, there is a chance of interactions among them during concomitant use. Hence, we carried out the research work to have an idea about the concomitant use of these drugs. We evaluated the interactions by monitoring UV, conductometric titration ${ }^{9-11}$ and Ardon's spectrophotometric methods ${ }^{12}$ of nandrolone with calcium nitrate, magnesium sulfate and potassium permanganate at the ratio of $1: 1$ at different $\mathrm{pHs}$.

\section{MATERIALS AND METHODS}

Apparatus. UV-visible spectrophotometer (Model- UV 1601, Shimadzu, Japan), Conductometer (Jenway, Switzerland), Cyclic voltameter (Shimadzu, Japan), centrifuge machine, $\mathrm{pH}$ meter (Mettler Toledo, Switzerland) were used for the analysis.

Drugs and chemicals. The working standards of nandrolone propionate, calcium nitrate (Merck, Germany), magnesium sulfate (Merck, Germany) and potassium permanganate (Merck, Germany) with potency of $98.80 \%, 98.50 \%, 99 \%$ and $99 \%$, respectively, were used. The nandrolone propionate was a gift of Techno Drugs Ltd., Dhaka, Bangladesh. Hydrochloric acid (37\%), potassium dihydrogen orthophosphate and orthophosphoric acid were purchased from Active Fine Chemicals Ltd., Bangladesh. Potassium chloride, potassium hydroxide, sodium hydroxide, potassium bromide and heparin were of reagent grade and purchased from Merck, Germany.

Preparation of buffer solutions ${ }^{9,10}$

pH 1.4. To prepare 1 litre of $\mathrm{pH} 1.4$ buffer, 6.57 $\mathrm{g}$ of potassium chloride was taken in a $1000 \mathrm{ml}$ volumetric flask and dissolved in $600 \mathrm{ml}$ of demineralized (DM) water. $119 \mathrm{ml}$ of $0.1 \mathrm{M} \mathrm{HCl}$ was added into the solution slowly. Finally the volume was made up to the mark with $\mathrm{DM}$ water. The $\mathrm{pH}$ was adjusted to 1.4 by using $\mathrm{HCl}$.

pH 3.4. This buffer was prepared by mixing of $302.80 \mathrm{ml}$ of $0.1 \mathrm{M}$ formic acid with $95 \mathrm{ml}$ of $0.1 \mathrm{M}$ $\mathrm{KOH}$ solution and diluted to $1000 \mathrm{ml}$ with DM water.

pH 6.4. This buffer was prepared by mixing of $302.1 \mathrm{ml}$ of $0.02 \mathrm{M} \mathrm{KH}_{2} \mathrm{PO}_{4}$ with $131.90 \mathrm{ml}$ of 0.01 $\mathrm{M} \mathrm{Na}_{2} \mathrm{HPO}_{4}$ and diluted to $1000 \mathrm{ml}$ by adding $\mathrm{DM}$ water.

pH 7.4. This buffer was prepared by mixing of $65.40 \mathrm{ml}$ of $0.02 \mathrm{M} \mathrm{KH}_{2} \mathrm{PO}_{4}$ with $289.70 \mathrm{ml}$ of $0.01 \mathrm{M}$ $\mathrm{Na}_{2} \mathrm{HPO}_{4}$ and diluted to $1000 \mathrm{ml}$ with $\mathrm{DM}$ water.

\section{Preparation of stock solutions}

Nandrolone. $100 \mathrm{ml}$ stock solution of $5 \times 10^{-3} \mathrm{M}$ was prepared by dissolving $0.165 \mathrm{~g}$ of nandrolone propionate in DM water and added 2-3 drops of methanol and chloroform to make it soluble. Finally, the volume was made up to $100 \mathrm{ml}$ with the same solvent. The stock solution was diluted to desired strength by buffer solutions.

Calcium nitrate. $100 \mathrm{ml}$ stock solution of $5 \times 10^{-3} \mathrm{M}$ was prepared by dissolving $1.18 \mathrm{~g}$ of calcium nitrate in DM water and made the volume up to $100 \mathrm{ml}$ with the same solvent. The stock solution was diluted to desired strength by buffer solutions.

Magnesium sulfate. $100 \mathrm{ml}$ stock solution of $5 \times 10^{-2} \mathrm{M}$ was prepared by dissolving $1.2825 \mathrm{~g}$ of magnesium sulfate in DM water and made the volume up to $100 \mathrm{ml}$ with the same solvent. The stock solution was diluted to desired strength by buffer solutions. 
Potassium permanganate. $100 \mathrm{ml}$ stock solution of $5 \times 10^{-2} \mathrm{M}$ was prepared by dissolving $0.79 \mathrm{~g}$ of potassium permanganate in DM water and made the volume up to $100 \mathrm{ml}$ with the same solvent. The stock solution was diluted to desired strength by buffer solutions.

\section{Analyses}

UV analysis. The ultraviolet absorption characteristics of nandrolone, calcium nitrate, magnesium sulfate and potassium permanganate and their 1:1 mixtures in different $\mathrm{pHs}(\mathrm{pH} 1.4,3.4,6.4$ and 7.4) were compared with those of each interacting drug. The concentrations of the samples were kept at very dilute levels in each case and the measurements were recorded between 200-400 nm using an UV-Vis spectrophotometer. The experiment was repeated thrice.

Conductometric analysis. Conductometric titrations were done to detect the complex formation of nandrolone, calcium nitrate, magnesium sulfate and potassium permanganate as well as to find the molar ratios of the interacting agent to the drug molecule in the complex. $40 \mathrm{ml}$ of $0.005 \mathrm{M}$ nandrolone solution was taken in a $100 \mathrm{ml}$ beaker and was titrated individually with gradual addition of $0.05 \mathrm{M}$ solution of calcium nitrate, magnesium sulfate and potassium permanganate from a burette. Reversely $40 \mathrm{ml}$ each of $0.05 \mathrm{M}$ calcium nitrate, magnesium sulfate and potassium permanganate were titrated with gradual addition of $0.005 \mathrm{M}$ nandrolone under similar conditions. The conductance values (mS) were plotted against molar ratios between the two agents in the system. The titrations curves showed break at the points of possible interaction. All the titrations were performed with solutions adjusted to $\mathrm{pH}$ 1.4, 3.4, 6.4 and 7.4.

The Ardon's method for analysis of drug-drug interaction. ${ }^{12}$ In this method, concentrations of drugs were varied while keeping the concentrations of the ligand was fixed. The absorbance of solutions having $\mathrm{pH}$ 1.4, 3.4, 6.4 and 7.4 were measured at $257 \mathrm{~nm}$ for nandrolone using UV-Vis spectrophotometer. For calculations, the following Ardon's equation ${ }^{10}$ was used -

$$
1 /\left(D-E_{A} C\right)=1 /\left(K C\left(E_{\text {com }}-E_{A}\right)[B]^{n}+1 / C\left(E_{\text {com }}-E_{A}\right)\right.
$$

Where,

$\mathrm{D}=$ absorbance of mixture

$\mathrm{C}=$ molar concentration of drug,

$\mathrm{B}=$ molar concentration of ligand (targeted drug)

$\mathrm{E}_{\text {com }}=$ molar extinction co-efficient of the complex

$\mathrm{E}_{\mathrm{A}}=$ molar extinction co-efficient of the drug

The value of $n$ was chosen as 1 , which is an essential condition for validation of the method. The value for $1 /\left(D-E_{A} C\right)$ was plotted versus $1 /[B]$ to get the straight lines. The concentration of nandrolone was kept constant at $5 \times 10^{-5} \mathrm{M}$ (denoted by $\mathrm{C}$ in the equation). The 1:1 complex gave a straight line in the plots with an intercept and slope. The stability constant of the complex was given by $\mathrm{K}=\mathrm{intercept} / \mathrm{slope}$. It is noted that the method is only valid for the systems where 1:1 complexes are found.

\section{RESULTS AND DISCUSSION}

When separated mixtures of nandrolone with calcium nitrate, magnesium sulfate and potassium permanganate at the ratio of $1: 1$ at the $\mathrm{pH}$ of 1.4, 3.4, 6.4 and 7.4 were studied at the range of 200 to 400 $\mathrm{nm}$ in UV-Vis spectrophotometer, the absorption maxima of nandrolone were found to be shifted (Figures 1 and 2). This alteration in spectral patterns might be regarded as an indicator for the primary interaction of drugs.

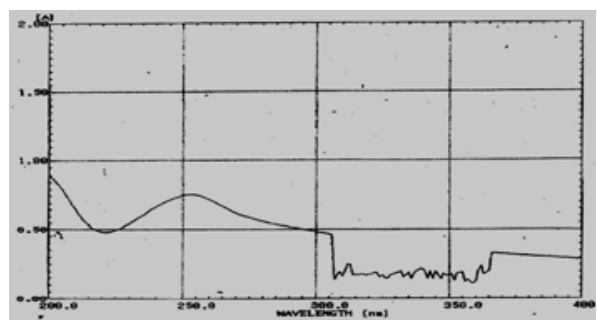

1-A

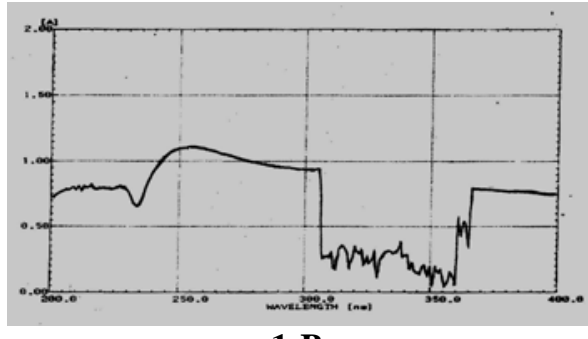

1-B

Figure 1. UV spectra of nandrolone pure drug (1-A) and nandrolone with calcium nitrate at $\mathrm{pH} 1.4$ (1-B) at $257 \mathrm{~nm}$. 


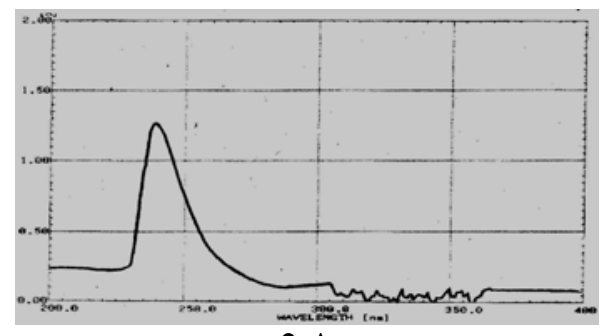

2-A

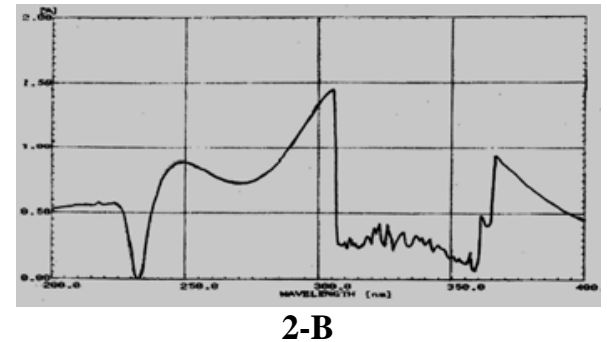

Figure 2. UV spectra of nandrolone with magnesium sulfate (2-A) and potassium permanganate (2-B) at pH 6.4 at $257 \mathrm{~nm}$.

The conductometric titrations in $\mathrm{DM}$ water at $\mathrm{pH}$ 6.4 were carried out to find the molar ratios at which complexation occurred. For each combination two titrations were carried out- one was titrated against the other and vice-versa. For each reacting species, the same process was followed. The conductance at each addition was recorded. Then the conductance was plotted versus the molar ratios of the titrants for obtaining conductivity curves (Tables 1- 3, Figure 3).

When nandrolone was titrated with calcium nitrate at $\mathrm{pH}$ 6.4, one distinct break corresponding to nandrolone-calcium nitrate molar ratios of 1:1 was found in the curve. The reverse titration also showed break at 1:1 molar ratio which indicated that nandrolone formed unstable complex with calcium nitrate at the molar ratio of 1: 1 .

Table 1. Data for conductometric titration of nandrolonecalcium nitrate at $\mathrm{pH}$ 6.4. Initial concentration of nandrolone $[\mathrm{B}]=0.005 \mathrm{M}$. Initial volume of nandrolone solution $=40 \mathrm{ml}$. Concentration of added species (calcium nitrate) $=\mathbf{0 . 0 5 M}$

\begin{tabular}{cccc}
\hline $\begin{array}{c}\text { Volume } \\
\text { of added } \\
\text { species } \\
(\mathrm{ml})\end{array}$ & $\begin{array}{c}\text { Conductance } \\
(\mathrm{mS}) \text { for } \\
\text { normal } \\
\text { titration }\end{array}$ & $\begin{array}{c}\text { Conductance } \\
(\mathrm{mS}) \text { for } \\
\text { reversed } \\
\text { titration }\end{array}$ & $\begin{array}{c}\text { Molar ratio (calciun } \\
\text { nitrate/nandrolone) } \\
{[\mathrm{A}] /[\mathrm{B}]}\end{array}$ \\
\hline 0 & 0.0 & 7.25 & 0.0 \\
1 & 0.12 & 7.01 & 0.25 \\
2 & 0.30 & 6.90 & 0.5 \\
3 & 0.45 & 6.69 & 0.75 \\
4 & 0.69 & 6.51 & 1.0 \\
5 & 0.88 & 6.35 & 1.25 \\
6 & 1.10 & 6.24 & 1.5 \\
7 & 1.33 & 6.15 & 1.75 \\
8 & 1.5 & 6.05 & 2.0 \\
\hline
\end{tabular}
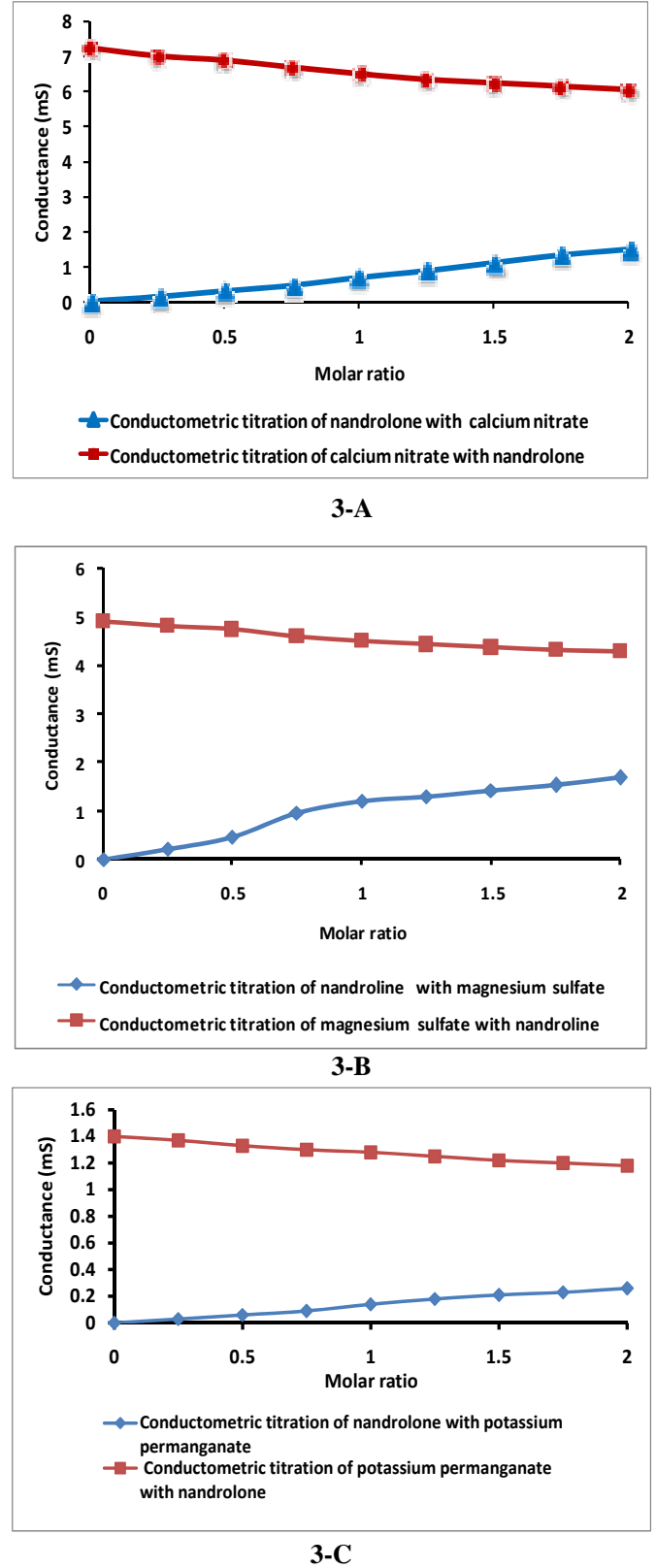

Figure 3. Curve for conductometric titration of nandrolone with calcium nitrate (3-A), magnesium sulfate (3-B) and potassium permanganate (3-C) at $\mathrm{pH} 6.4$.

The same titration of nandrolone with mixture of magnesium sulfate was carried out at $\mathrm{pH}$ 6.4. It showed a distinct break at 1:1 molar ratio, where as the reverse titration also showed a break at 1:1 molar ratio which also indicated the complex formation of nandrolone with magnesium sulfate. The nandrolone solution was also titrated with potassium permanganate at $\mathrm{pH} 6.4$ showed distinct breaks at 1:1 molar ratio, which the reverse titration also showed. 
This indicated that the nandrolone also formed an unstable complex with potassium permanganate at 1:1 molar ratio. From the above discussions revealed that nandrolone does not form any stable complex with calcium nitrate, magnesium sulfate and potassium permanganate at the molar ratio of $1: 1$ at pH 6.4.

Table 2. Data for conductometric titration of nandrolonemagnesium sulfate at $\mathbf{p H}$ 6.4. Initial concentration of nandrolone $[\mathrm{B}]=0.005 \mathrm{M}$. Initial volume of nandrolone solution $=40 \mathrm{ml}$. Concentration of added species (magnesium sulfate $)=0.05 \mathrm{M}$

\begin{tabular}{cccc}
\hline $\begin{array}{c}\text { Volume } \\
\text { of added } \\
\text { species } \\
(\mathrm{ml})\end{array}$ & $\begin{array}{c}\text { Conductance } \\
(\mathrm{mS}) \text { for } \\
\text { normal } \\
\text { titration }\end{array}$ & $\begin{array}{c}\text { Conductance } \\
\text { (mS) for } \\
\text { reversed } \\
\text { titration }\end{array}$ & $\begin{array}{c}\text { Molar ratio } \\
\text { (magnesium sulfate } \\
\text { /nandrolone) } \\
\text { [A]/[B] }\end{array}$ \\
\hline 0 & 0.0 & 4.90 & 0.0 \\
1 & 0.20 & 4.80 & 0.25 \\
2 & 0.45 & 4.73 & 0.5 \\
3 & 0.95 & 4.60 & 0.75 \\
4 & 1.20 & 4.50 & 1.0 \\
5 & 1.30 & 4.42 & 1.25 \\
6 & 1.42 & 4.36 & 1.5 \\
7 & 1.52 & 4.31 & 1.75 \\
8 & 1.68 & 4.28 & 2.0 \\
\hline
\end{tabular}

Table 3. Data for conductometric titration of nandrolonepotassium permanganate at $\mathrm{pH}$ 6.4. Initial concentration of nandrolone $[\mathrm{B}]=0.005 \mathrm{M}$. Initial volume of nandrolone solution $=40 \mathrm{ml}$. Concentration of added species (potassium permanganate) $=0.05 \mathrm{M}$.

\begin{tabular}{cccc}
\hline $\begin{array}{c}\text { Volume of } \\
\text { added } \\
\text { species } \\
(\mathrm{ml})\end{array}$ & $\begin{array}{c}\text { Conductan } \\
\text { ce (mS) for } \\
\text { normal } \\
\text { titration }\end{array}$ & $\begin{array}{c}\text { Conductance } \\
\text { (mS) for } \\
\text { reversed } \\
\text { titration }\end{array}$ & $\begin{array}{c}\text { Molar ratio } \\
\text { (potassium } \\
\text { permanganate } \\
\text { /nandrolone) [A]/[B }\end{array}$ \\
\hline 0 & 0.0 & 1.40 & 0.0 \\
1 & 0.03 & 1.37 & 0.25 \\
2 & 0.06 & 1.33 & 0.5 \\
3 & 0.09 & 1.30 & 0.75 \\
4 & 0.14 & 1.28 & 1.0 \\
5 & 0.18 & 1.25 & 1.25 \\
6 & 0.21 & 1.22 & 1.5 \\
7 & 0.23 & 1.20 & 1.75 \\
8 & 0.26 & 1.18 & 2.0 \\
\hline
\end{tabular}

Ardon's plot confirmed the formation of 1:1 complexes of nandrolone with calcium nitrate, magnesium sulfate and potassium permanganate. Stability constants (K) for nandrolone-calcium nitrate, nandrolone-magnesium sulfate and nandrolone-potassium permanganate systems were obtained from the ratio between the intercepts (c) and slopes (m) of the Ardon's plots, i. e. $\mathrm{K}=\mathrm{c} / \mathrm{m}$. The calculated stability constants $(\mathrm{K})$ for different systems are given in the table (Tables 4-6, Figures 4 and 5). It was found that the values of stability constant for the systems remain quite close to each other at pHs 1.4 and 6.4 except for nandrolonecalcium nitrate system which was found to be different than other (3.49 and 1.31, respectively).

Table 4. Stability constants (K) for different systems.

\begin{tabular}{lcc}
\hline \multirow{1}{*}{ Systems } & \multicolumn{2}{c}{ Stability constants $\mathrm{K} \mathrm{x} 10^{-5} / \mathrm{mole}$} \\
\cline { 2 - 3 } & $\mathrm{pH} \mathrm{1.4}$ & $\mathrm{pH} \mathrm{6.4}$ \\
\hline $\begin{array}{l}\text { Nandrolone-calcium } \\
\text { nitrate }\end{array}$ & 3.49 & 1.31 \\
$\begin{array}{l}\text { Nandrolone-magnesium } \\
\text { sulfate }\end{array}$ & 2.23 & 2.87 \\
$\begin{array}{l}\text { Nandrolone-potassium } \\
\text { permanganate }\end{array}$ & 6.75 & 4.06 \\
\hline
\end{tabular}

Table 5. Values for Ardon's plot at pH 1.4. Concentration of nandrolone $[\mathrm{C}]=5 \times 10^{-5} \mathrm{M}$. Absorbance of $5 \times 10^{-5} \mathrm{M}$ nandrolone $=0.4028$. Molar extinction co-efficient of nandrolone, $\mathrm{E}_{\mathrm{A}}=\mathbf{8 0 5 6}$

Table 5A. Nandrolone-calcium nitrate system

\begin{tabular}{cccc}
\hline $\begin{array}{c}\text { Conc. of calcium } \\
\text { nitrate [B], Mx10 }\end{array}$ & $\begin{array}{c}\text { Abs. of } \\
\text { mixture [D] }\end{array}$ & $1 /\left(\mathrm{D}-\mathrm{E}_{\mathrm{A}} \mathrm{C}\right)$ & $\begin{array}{c}1 /([\mathrm{B}] \mathrm{x} \\
\left.10^{-5}\right)\end{array}$ \\
\hline 1.00 & 0.4682 & 15.29 & 10.00 \\
1.50 & 0.4857 & 12.06 & 6.67 \\
2.00 & 0.4957 & 10.76 & 5.00 \\
2.50 & 0.5089 & 9.43 & 4.00 \\
3.00 & 0.5247 & 8.20 & 3.33 \\
3.50 & 0.5328 & 7.69 & 2.86 \\
4.00 & 0.5469 & 6.94 & 2.50 \\
4.50 & 0.5528 & 6.67 & 2.22 \\
5.00 & 0.5617 & 6.29 & 2.00 \\
\hline
\end{tabular}

Table 5B. Nandrolone-magnesium sulfate system

\begin{tabular}{cccc}
\hline $\begin{array}{c}\text { Conc. of } \\
\text { magnesium sulfate } \\
{[\mathrm{B}],{\mathrm{Mx} 10^{-5}}^{-5}}\end{array}$ & $\begin{array}{c}\text { Abs. of } \\
\text { mixture [D] }\end{array}$ & $1 /\left(\mathrm{D}-\mathrm{E}_{\mathrm{A}} \mathrm{C}\right)$ & $\begin{array}{c}1 /([\mathrm{B}] \mathrm{x} \\
\left.10^{-5}\right)\end{array}$ \\
\hline 1.00 & 0.4829 & 12.48 & 10.00 \\
1.50 & 0.5158 & 8.85 & 6.67 \\
2.00 & 0.5349 & 7.57 & 5.00 \\
2.50 & 0.5526 & 6.68 & 4.00 \\
3.00 & 0.5782 & 5.70 & 3.33 \\
3.50 & 0.5928 & 5.26 & 2.86 \\
4.00 & 0.6147 & 4.72 & 2.50 \\
4.50 & 0.6358 & 4.29 & 2.22 \\
5.00 & 0.6528 & 4.00 & 2.00 \\
\hline
\end{tabular}

Table 5C. Nandrolone-potassium permanganate system.

\begin{tabular}{cccc}
\hline $\begin{array}{c}\text { Conc. of } \\
\text { potassium } \\
\text { permanganate [B], } \\
\text { Mx10-5 }\end{array}$ & $\begin{array}{c}\text { Abs. of } \\
\text { mixture [D] }\end{array}$ & $1 /\left(\mathrm{D}-\mathrm{E}_{\mathrm{A}} \mathrm{C}\right)$ & $\begin{array}{c}1 /([\mathrm{B}] \mathrm{x} \\
\left.10^{-5}\right)\end{array}$ \\
\hline 1.00 & 0.4662 & & \\
1.50 & 0.4726 & 15.77 & 10.00 \\
2.00 & 0.4829 & 12.48 & 6.67 \\
2.50 & 0.4898 & 11.49 & 4.00 \\
3.00 & 0.4925 & 11.15 & 3.33 \\
3.50 & 0.4991 & 10.38 & 2.86 \\
4.00 & 0.5017 & 10.11 & 2.50 \\
4.50 & 0.5147 & 8.94 & 2.22 \\
5.00 & 0.5182 & 8.67 & 2.00 \\
\hline
\end{tabular}




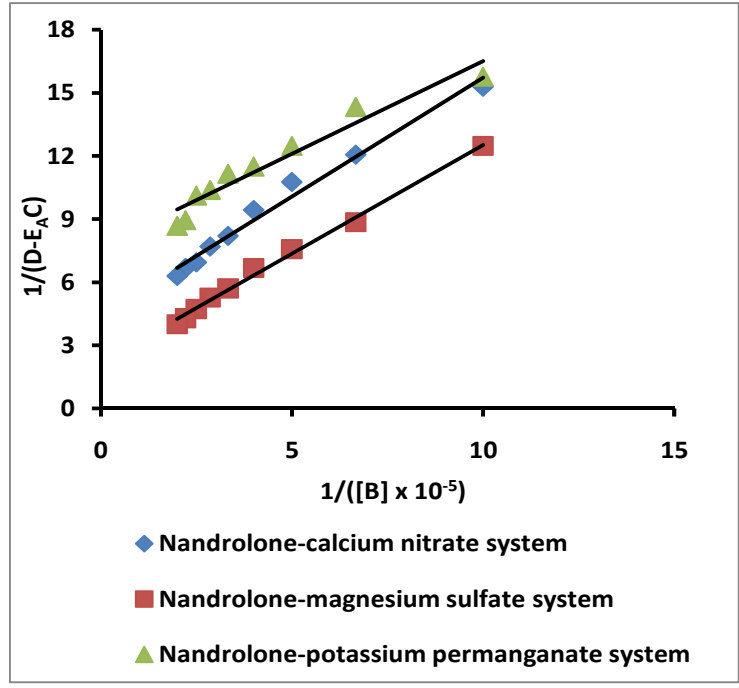

Figure 4. Ardon's plot at pH 1.4.

Table 6. Values for Ardon's plot at pH 6.4. Concentration of nandrolone $[\mathrm{C}]=5 \times 10^{-5} \mathrm{M}$. Absorbance of $5 \times 10^{-5} \mathrm{M}$ nandrolone $=0.3849$. Molar extinction co-efficient of nandrolone, $\mathrm{E}_{\mathrm{A}}=\mathbf{0 6 9 8}$

Table 6A. Nandrolone-calcium nitrate system

\begin{tabular}{cccc}
\hline $\begin{array}{c}\text { Conc. of calcium } \\
\text { nitrate [B], Mx10 }\end{array}$ & $\begin{array}{c}\text { Abs. of } \\
\text { mixture [D] }\end{array}$ & $1 /\left(\mathrm{D}-\mathrm{E}_{\mathrm{A}} \mathrm{C}\right)$ & $\begin{array}{c}1 /([\mathrm{B}] \\
\left.\mathrm{x} 10^{-5}\right)\end{array}$ \\
\hline 1.00 & 0.4628 & 12.84 & 10.00 \\
1.50 & 0.4800 & 10.52 & 6.67 \\
2.00 & 0.4961 & 8.99 & 5.00 \\
2.50 & 0.5429 & 6.33 & 4.00 \\
3.00 & 0.5682 & 5.46 & 3.33 \\
3.50 & 0.5891 & 4.90 & 2.86 \\
4.00 & 0.6048 & 4.55 & 2.50 \\
4.50 & 0.6453 & 3.84 & 2.22 \\
5.00 & 0.6812 & 3.37 & 2.00 \\
\hline
\end{tabular}

Table 6B. Nandrolone-magnesium sulfate system

\begin{tabular}{cccc}
\hline $\begin{array}{c}\text { Conc. of magnesium } \\
\text { sulfate [B], Mx10 }\end{array}$ & $\begin{array}{c}\text { Abs. of } \\
\text { mixture [D] }\end{array}$ & $1 /\left(\mathrm{D}-\mathrm{E}_{\mathrm{A}} \mathrm{C}\right)$ & $\begin{array}{c}1 /([\mathrm{B}] \\
\left.\mathrm{x} \mathrm{10}^{-5}\right)\end{array}$ \\
\hline 1.00 & 0.5482 & 6.12 & 10.00 \\
1.50 & 0.5924 & 4.82 & 6.67 \\
2.00 & 0.6348 & 4.00 & 5.00 \\
2.50 & 0.6725 & 3.48 & 4.00 \\
3.00 & 0.7129 & 3.05 & 3.33 \\
3.50 & 0.7426 & 2.80 & 2.86 \\
4.00 & 0.7928 & 2.45 & 2.50 \\
4.50 & 0.8254 & 2.27 & 2.22 \\
5.00 & 0.8567 & 2.12 & 2.00 \\
\hline
\end{tabular}

Table 6C. Nandrolone-potassium permanganate system

\begin{tabular}{cccc}
\hline $\begin{array}{c}\text { Conc. of potassium } \\
\text { permanganate [B], } \\
\text { Mx10 }\end{array}$ & $\begin{array}{c}\text { Abs. of } \\
\text { mixture [D] }\end{array}$ & $1 /\left(\mathrm{D}-\mathrm{E}_{\mathrm{A}} \mathrm{C}\right)$ & $\begin{array}{c}1 /([\mathrm{B}] \\
\left.\mathrm{x} 10^{-5}\right)\end{array}$ \\
\hline 1.00 & 0.4465 & 16.23 & 10.00 \\
1.50 & 0.4552 & 14.22 & 6.67 \\
2.00 & 0.4649 & 12.50 & 5.00 \\
2.50 & 0.4764 & 10.93 & 4.00 \\
3.00 & 0.4802 & 10.49 & 3.33 \\
3.50 & 0.4889 & 9.62 & 2.86 \\
4.00 & 0.4928 & 9.27 & 2.50 \\
4.50 & 0.5098 & 8.01 & 2.22 \\
5.00 & 0.5148 & 7.70 & 2.00 \\
\hline
\end{tabular}

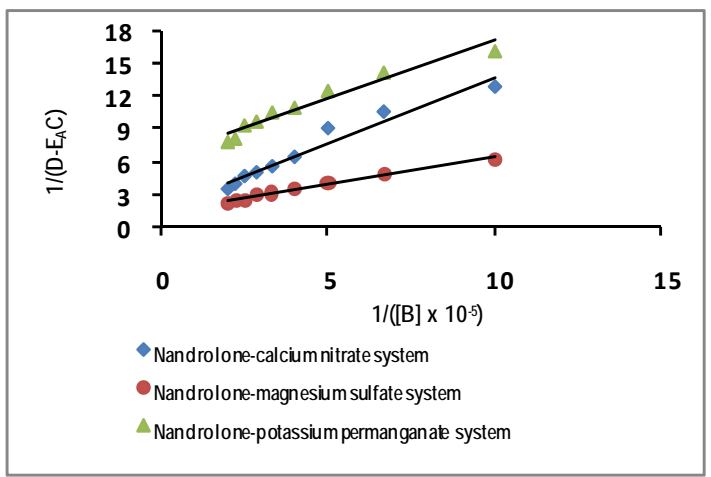

Figure 5. Ardon's plot at pH 6.4.

\section{CONCLUSION}

Since nandrolone has been prescribed frequently with the minerals like calcium nitrate, magnesium sulfate and potassium permanganate for concurrent use, the principal purpose of the present study was to investigate in vitro complex formation of nandrolone with such minerals and to study the nature and strength of the complexes which could be formed from the interactions. The interactions were studied in the aqueous systems at room temperature at different pHs by a variety of physical methods to detect and confirm the nature of complexation of these drugs. It was found that nandrolone did not form any stable complexes at the ratio of 1:1 with the salts. Initially, absorption spectral analysis showed that unstable complexes were formed but conductometric titration indicated that there was a very rare chance of the formation of complexes between nandrolone and these metal ions. The Ardon's spectrophotometric analysis confirmed that the values of stability constant for the nandrolonecalcium nitrate, nandrolone-magnesium sulfate and nandrolone-potassium permanganate systems remain quite close to each other at the ratio of $1: 1$ at $\mathrm{pHs} 1.4$ and 6.4 except for nandrolone-calcium nitrate system which was found to be different than other (3.49 and 1.31, respectively). Therefore, it was concluded that at $\mathrm{pH} 1.4$ and 6.4, nandrolone-calcium nitrate system formed stable complexes while other systems formed relatively weak complexes. 


\section{REFERENCES}

1. Ahsan, M. R., Sultan, M. Z., Baki, M. A., Rahman, M. A., Hossain, M. A., Hossain, M. A., Amran, M. S. 2011. The study of in vitro and in vivo effects of concurrent administration of paracetamol and zinc on the antibacterial activity of ciprofloxacin. Dhaka Univ. J. Pharm. Sci. 10, 137142.

2. Brunton, L. L., Lazo, J. S., and Parker, K. L. 2005. Goodman \& Gilman's The Pharmacological Basis of Therapeutics. The McGraw-Hill Companies, Inc., $11^{\text {th }}$ edition, pp. 26-60.

3. Kundu, S., P., Amjad, F. A., Sultana, S., Sultan, M. Z., Hossain, M. A. and Amran, M. S. 2012. Study of differential scanning calorimetry of complex of magnesium sulfate with aspirin, paracetamol and naproxen. Bangladesh Pharm. J. 15, 7-12.

4. Ahsan, M. R., Sultan, M. Z., Amjad, F. M., Sultana, S., Baki, M. A., Hossain, M. A., Hossain, M. A. and Amran, S. M. 2012. The study of in vitro interaction of ciprofloxacin with paracetamol and zinc in aqueous medium. J. Sci. Res. 4, 701-708.
5. Craig, R. C. and Stitzel, R. E. 2003. Modern pharmacology with clinical applications. Lippincott Williams \& Wilkins; Sixth edition, p. 730.

6. British National Formulary, Royal Pharmaceutical Society1Lambeth High Street, London, SE1 7JN, UK 461, 61st edition, 2011.

7. Remington, The Science and Practice of Pharmacy, Vol. II, Mack Publishing Company, Easton, Pennsylvania, USA, 19th edition, 1995.

8. United States Pharmacopoeia 30 - National Formulary 25 (USP 30 - NF 25), United States Pharmacopeial Convention, Rockville, MD, 2007.

9. Perrin, D. D. and Boyd, D. 1974. Buffer for $\mathrm{pH}$ and metal ion control, Science Papers Back, New York, pp. 44 - 64.

10. Bates, R. G.1973. Determination of $\mathrm{pH}$, Theory and Practice. 2nd ed. John Wiley \& Sons, Inc., New York, N. Y. 10016, pp. 50-67.

11. Vogel, A. I. 1961. A Textbook of Quantitative Inorganic Analysis. 3rd edition, Longmans, London, p. 93.

12. Ardon, M. 1957. Oxidation of ethanol by ceric perchlorate. $J$. Chem. Soc. 1811-1815. DOI: 10.1039/JR9570001811. 